\title{
Kontribusi Hermeneutis 1 Raja-Raja 21 terhadap Konflik Agraria di Indonesia
}

\author{
Admadi Balloara Dase \\ Sekolah Tinggi Agama Kristen Negeri Toraja, Tana Toraja, Sulawesi Selatan \\ admadiballoaradase777@gmail.com
}

\begin{abstract}
Agrarian conflict is a very classic discussion in Indonesia. It affects humanity, and environmental issues. As many discriminations happens toward marginalized society, it's needed to be a concern. The author will dialogue this issue with text 1 Kings 21 . This event is almost the same with the text 1 Kings 21, about the seizure of land between King Ahab and Naboth. To investigate and review the meaning of 1 Kings 21, the author uses critical history method. In conclusion, greed is the cause, so there was a land seizure between King Ahab and Nabot which resulted in the killing of Nabot as a weaker person. However, God declared justice for His people, and declared judgment on King Ahab. The event like this also often occured in Indonesian society, due to economic interests and the legitimacy of national development. However, it is unfortunate that the prophetic voice from the church could not be heard.
\end{abstract}

Keyword: 1 Kings 21; agrarian conflict; hermeneutics; oppression

\begin{abstract}
Abstrak: Konflik agraria merupakan persoalan yang sangat klasik di Indonesia. Konflik tersebut berdampak pada kemanusiaan, bahkan pada masalah lingkungan. Dengan banyaknya terjadi diskriminasi terhadap orang-orang marginal (tak berdaya) tentunya ini perlu menjadi perhatian. Penulis akan mencoba melihat impikasi dari teks 1 raja-raja 21 terhadap konteks saat ini. Peristiwa diskriminasi tersebut tentunya hampir sama terjadi dalam teks 1 Raja-raja 2, tentang perebutan tanah antara raja Ahab dan Nabot. Dalam menyelidiki dan mengkaji makna dari 1 Raja-raja 21, penulis mengunakan metode penafsiran kritik sejarah (historis). Kesimpulannya, keserakahan yang menjadi penyebab, sehingga terjadi perebutan tanah antara Raja Ahab dan Nabot yang mengakibatkan terbunuhnya Nabot sebagai yang lemah. Namun, Tuhan tetap menyatakan keadilannya bagi umat-Nya, dan menyatakan penghakiman kepada raja Ahab. Peristiwa tersebut juga sering terjadi dalam masyarakat Indonesia, dikarenakan kepentingan ekonomi dan legitimasi pembangunan nasional. Namun, sangat disayangkan gaungan suara kenabian dari gereja tak begitu terdengar.
\end{abstract}

Kata Kunci: 1 raja-raja 21; hermeneutik; konflik agrarian; penindasan

\begin{tabular}{llll}
\hline Article History : & Received: 16-03-2019 & Revised: 10-04-2019 & Accepted: 06-05-2019 \\
\hline
\end{tabular}




\section{Pendahuluan}

Konflik agraria sering kali terjadi. Di Indonesia sendiri hal ini telah terjadi sejak zaman feodal, yang merupakan implikasi dari ketakutan dan kegelisahan petani atas pengambilan tanah mereka secara paksa oleh pihak kerajaan (bangsawan). Sehingga sering terjadi konflik antara bangsawan dan rakyat. Dalam hal ini, VOC mengambil keuntungan untuk menganti kebijakan kekuasaan bangsawan (Feodal), dengan menaklukan para bangsawan dan mengambil alih atas kekuasaannya, maka tanah yang dimiliki oleh para bangsawan juga secara otomatis akan beralih kepada pemerintahaan belanda, dan menjadi keuntungan bagi VOC sendiri. ${ }^{1}$ Bahkan diperparah pada tahun 1930, Van den Bosch membuat kebijakan akan sistem tanam paksa. Kebijakan ini sangatlah merugikan para petani, yang mengakibatkan penderitaan di jawa, serta mendapat kecaman dari segolongan orang belanda sendiri.

Jikalau melihat sejarahnya, konflik agraria sangatlah panjang, bahkan hal tersebut masih saja terjadi sampai saat ini, dalam situasi yang berbeda. Perebutan lahan dilakukan oleh para penguasa, dan bekerja sama dengan pemilik modal. Di tahun 20042015, konflik agraria di Indonesia ada 1.772 kasus, luas wilayah konflik sekitar 6,9 juta hektar. ${ }^{2}$ Dari total jumlah ini, konflik agraria melibatkan 1.085.817 kepala keluarga (KK). Pada 2015 saja, total konflik yang terjadi adalah 252 kejadian dengan luasan mencapai 400.430 hektar dan melibatkan 108.714 KK. $^{3}$ Sementara itu, jika melihat dari sisi korban, sepanjang 2015 konflik agraria telah mengakibatkan 5 orang tewas, 39 orang tertembak aparat, 124 orang luka-luka karena penganiayaan, dan 278 orang mengalami kriminalisasi atau ditahan. ${ }^{4}$ Dan tentu ini menjadi kegelisahan tersendiri bagi bangsa Indonesia, atas perampasan hak-hak mereka yang kecil dan tak berdaya.

Pristiwa perebutan lahan juga dinarasikan oelh Alkitab Perjanjian Lama, yaitu I Raj. 21:1-10 berkisah: ada seorang warga masyarakat Israel bernama Nabot. Ia mempunyai kebun anggur yang letaknya berdekatan dengan istana raja Ahab (ay 1). Pada suatu hari sang raja ingin memiliki kebun anggur itu (ay 2). Namun Nabot tidak mau memberikannya, dengan alasan karena tanah itu adalah hak warisnya (ay 3). Akibatnya sang raja menjadi stress dan tidak mau makan (ay 4). Melihat keadaan sang raja seperti itu, Izebel sang permaisuri lalu membuat surat kaleng yang isinya mengatakan Nabot telah mengutuk Allah dan raja. Tujuan Izebel adalah membawa Nabot ke pengadilan agama demi mendapatkan kebun anggur Nabot (ay 5-10). Pada gilirannya Nabot sang rakyat kecil yang tidak berdaya itu, mati dilempari dengan batu. Sedangkan Ahab

${ }^{1}$ Al Araf, Awan Puryadi, Perebutan Tanah (Yogyakarta: Lappera, 2002), 55.

${ }^{2}$ Arimbi Ramadhiani, "Konflik Agraria Dipicu Ekspansi Perkebunan, Properti, dan Infrastruktur" http://properti.kompas.com/read/2016/01/06/100000821/Sejak.2004.Konflik.Agraria.Mencapai.1.772.Kas us (Diakses pada 13 Mei 2016).

3Ibid.

4Ibid. 
bersama Izebel sang penguasa berhasil memiliki sebidang kebun anggur tersebut, dengan cara yang sangat licik (ayat 11-16).

Oleh karena itu penulis ingin mencoba meneliti masalah agraria, khususnya di Indonesia, di mana masalah tersebut sangatlah krusial bagi negara, karena terjadi kriminalisasi terhadap orang-orang yang termarginalkan. Dengan menafsirkan teks 1 Raja-raja 21, kiranya dapat memberi sumbangsih terhadap masalah agraria di Indonesia, dan menjadi inshigt, untuk menolak diskriminasi, kriminalisasi terhadap orang-orang kecil. Sehingga, penulis akan mencoba melihat apa sumbangsih teologi perjanjian lama khususnya di teks 1 Raja-raja 21 dalam konflik agraria di Indonesia?

\section{Metode Penelitian}

Perjalanan penafsiran di dalam tulisan ini, penulis akan mengunakan kritik historis. Kritik Historis merupakan model yang berusaha melepaskan diri dari sistem atau ajaran tertentu, meskipun dalam kenyataan sulit berbuat seperti itu. Biasanya yang terjadi orang dilepaskan dari sistem A, tetapi diam-diam dimasukan ke dalam sistem B. Langkah pertamanya sama dengan model non/praktis. Teks mula-mula diperhatikan dalam kerangka konteks. Hal ini dilakukan dalam dua tahap: mula-mula dalam pengertian konteks dari teks. Ayat atau periop-perikop yang ditafsir, dan dibaca dalam kerangka ayat-ayat atau perikop yang mendahului dan menyusuli. Dengan demikian, tafsir tidak sekadar mencomot ayat-ayat atau perikop dari konteks, melainkan juga memahami dalam konteks. Kemudian konteks dari teks diasumsikan membawa kita pada konteks historis. Hal ini biasanya disebut Sitz im Leben, yang dapat berarti "situasi dalam kehidupan." 5

Tetapi, sebenarnya berarti usaha menempatkan teks dalam situasi sejarah, budaya atau masyarakat tertentu di masa lalu. Sekarang ditambah lagi dengan kemajuan di bidang sosiologi atau ilmu sosial, maka situasi ini biasanya disebut setting sosiologis. Bisa terjadi bahwa perjalanan dari konteks teks ke konteks historis teks, mendorong penafsir untuk mengecek kehistorian dari uraian teks. ${ }^{6}$ Dengan demikian, salah satu ciri dari tafsir kritis-historis adalah pertanyaan tentang kehistorisan teks, pembaca atau pendengar si penafsir diajak masuk ke dalam dunia penulis. Penafsir yakin bahwa melalui model ini ia dapat masuk ke dalam niat atau maksud penulis. ${ }^{7}$

Teks adalah jawaban penulis bagi situasi tertentu di zaman penulis yang sedang mengalami krisis, dan teks berusaha menjawab krisis ini, bisa dengan sukses tetapi bisa saja dengan tidak begitu sukses. Tetapi, jikalau sukses dimasa lalu, harap diperhatikan belum tentu teks menjawab situasi kita dimasa kini. Jadi tidak ada loncatan yang langsung dari masa lalu ke masa kini, dan tidak mengherankan kalau ada hasil tafsir kritis-historis yag tidak langsung menjawab kebutuhan masa kini. Kalau hasil teksnya

${ }^{5}$ Emmanuel G. Singgih, Dua Konteks (Jakarta:BPK Gunung Mulia,2009), x-xi.

${ }^{6}$ Ibid.

7Ibid. 
negatif, apabila ditinjau dari kriteria masa kini, maka jawabannya bisa sederhana sekali: teks tidak lagi relevan untuk masa kini. ${ }^{8}$

Adapun langkah yang di lakukan ketika memakai pendekatan Kritik historis yang pertama membicarakan soal sejarah dalam teks, atau situasi yang digambarkan teks. Sarana yang paling tepat untuk medapatkan keterangan mengenai hal-hal ini biasanya adalah kamus-kamus dan ensiklopedi Alkitab, dan sarana yang paling berguna untuk diperhatikan adalah buku-buku mengenai sejarah Israel kuno dan kekristenan mulamula. Sumber-sumber yang tidak tercakup dalam Alkitab tetapi dapat dijadikan sebagai pembanding, dapat dipakai untuk memperjelas situasi yang digambarkan oleh teks Alkitab sendiri. ${ }^{9}$

Dimensi kesejarahan yang kedua yang harus diteliti oleh penafsir adalah sejarah teks, adalah sejarah dari teks, atau situasi yang dari dalam teks muncul yakni situasi pengarang dan pendengar atau pembacanya. Namun harus diakui bahwa banyak tulisan alkitabiah sebenarnya merupakan karya suntingan ketimbangkan karya suntingan ketimbang karya satu orang penulis. Hal ini mengharuskan para penafsir mengubah atau menggeser pemahaman mereka mengenai hubungan antara tulisan-tulisan Alkitabiah dengan para pengirim dan penerima mula-mulanya. ${ }^{10}$

Karena bentuk akhir teks Alkitabiah seringkali merupakan hasil penyuntingan yang luas, maka sebuah kitab dapat berisi unit-unit yang hubungannya satu sama lain sama sekali tidak jelas. Unit-unit atau bagian-bagiannya itu boleh disisipkan, atau ditambahkan kedalam tulisan semula. Penafsir tidak dapat beranggapan bahwa konteks sejarah yang sama telah melahirkan semua dokumen itu, tetapi sebaliknya ia harus terbuka pada aneka ragam kemungkinan konteks historis. ${ }^{11}$

Aspek ketiga dari sejarah eksternal suatu bagian tulisan alkitabiah dapat disebutkan. Aspek ini bersangkutan dengan cara yang di dalamnya bagian-bagian tertentu Alkitab memasukan tradisi-tradisi alkitabiah yang lebih tua dan menafsirkannya kembali dengan menyajikan dalam bentuk yang baru sudah diubah. ${ }^{12}$ Hal ini menyadarkan penafsir bahwa banyak bahan alkitabiah asal-usulnya berkaitan, dalam arti bahwa bahan-bahan yang ada lebih dulu diambil alih, dibawa masuk dan disajikan kembali dalam bahan-bahan yang lebih kemudian. Dengan demikian Alkitab dapat dipandang telah mengalami perkembangan historis. ${ }^{13}$

\section{Makna Tanah Bagi Orang Israel}

Sebelum masuk dalam teks 1 raja-raja 21, penulis akan mencoba menjelaskan pemahaman bangsa Israel tentang tanah. Karena di dalam narasi 1 raja-raja 21, ada perebutan

\footnotetext{
${ }^{8}$ Singgih, Dua Konteks, $x-x i$

9John H. Hayes, Carl R. Holladay, Pedoman Penafsiran Alkitab (Jakarta: Bpk. Gunung Mulia, 2013), 55.

10Ibid., 57.

${ }^{11}$ Hayes, Holladay, Pedoman Penafsiran Alkitab, 59.

12Ibid., 60.

13Ibid., 60-61.
} 
tanah antara raja Ahab dan Nabot. Nabot menolak bertransaksi dengan Raja Ahab, untuk perpindahan kepemilikan tanahnya. Mengapa Nabot menolak? Dari pertanyaan penting itulah kita dapat paham persoalan dalam 1 Raja-raja 21. Paling tidak, pemaknaan tanah bagi bangsa Israel dapat menjadi kunci untuk masuk kedalam persoalan inti dalam tulisan ini.

Bagi bangsa Israel sendiri, tanah perjanjian mempunyai makna yang penting. Tanah adalah simbol perjnajian Tuhan kepada bangsa Israel melalui Abraham dalam teks Kej. 12:1, “...Pergilah dari negerimu dan dari sanak saudaramu dan dari rumah bapamu ini ke negeri yang akan Kutunjukkan kepadamu." Tuhan berjanji memberikan tanah untuk Abraham dan keturunanya. Peristiwa pemberian ini merupakan satu pokok pujian pujian, dasar kepercayaan dan pengharapan bagi Israel, namun juga satu amanat untuk menguduskan hidupnya sebagai umat Tuhan didalam tanah milik Tuhan sendiri. Israel dan tanah, dua entitas yang tak terpisahkan dalam Perjanjian Lama. Sejarah bangsa Israel di Perjanjian Lama boleh dikatakan berpusat pada tanah perjanjian, bahkan kapan dan di mana pun bangsa Israel selalu merindukan tanah itu, karena dari peristiwa tersebut Tuhan terlibat dengan mereka.

Tanah juga merupakan sebuah simbol bahwa bangsa Israel memiliki suatu hubungan yang istimewa dengan Allah. Relasi tersebut seperti hubungan seorang ayah dan anak sulung. Sehingga, kehilangan tanah mengancam kedudukan seorang Israel, mereka tidak mau kehilangan tanah keluarga dan hal itu dijamin Taurat. ${ }^{14}$ Layaklah bagi bangsa Israel, tanah sangat penting bagi mereka, bukan hanya persoalan kepemilikan, tetapi tanah itu juga menyangkut hubungan mereka dengan Allah sendiri.

Peristiwa pemberian ini merupakan satu pokok puji pujian, dasar kepercayaan dan pengharapan bagi Israel, namun juga satu amanat untuk menguduskan hidupnya sebagai umat Tuhan didalam tanah milik Tuhan sendiri. Israel dan tanah, dua entitas tak terpisahkan dalam Perjanjian Lama. Sejarah bangsa Israel di Perjanjian Lama boleh dikatakan berpusat pada tanah perjanjian, bahkan kapan dan dimanapun bangsa Israel selalu merindukan tanah itu, karena disitulah Tuhan terlibat dengan mereka. Bahkan sampai pada era Perjanjian Baru, harapan akan tanah tersebut tidak pernah sirna dari memori kolektif bangsa Israel. ${ }^{15}$

Bangsa Israel sangat dekat dengan tanah. Sebab dari tanah, bangsa Israel mengingat penyertaan Tuhan, bahkan janji-janji keselamatan dari-Nya (Yes. 14:1-2). Maka, dari peristiwa tersebut, terbentuk identitas bangsa Israel sebagai umat Allah. Tidak hanya sampai kepada pembentukan Identitas. Tetapi, narasi sejarah dalam perjanjian lama yang merupakan hubungan antara Allah dan Umatnya, berbicara mengenai tanah,

\footnotetext{
${ }^{14}$ Yonky Karman, Bunga Rampai Teologi Perjanjian Lama (Jakarta: BPK. Gunung Mulia, 2013), 81.

${ }^{15}$ Yohanes Krismantyo Susanta. "Anak Manusia: Suatu Reinterpretasi terhadap Konsep Mesianis Yahudi." (2014). http://repository.seabs.ac.id/handle/123456789/304 (diakses 25 Mei 2019).
} 
sebagai legalitas sebuah perjanjian. Ini menunjukan bahwa tanah menjadi hal yang penting dari kehidupan holistik bangsa Israel. 16

Tanah diberikan untuk memenuhi kehidupan sehari-hari keluarga-keluarga Israel. Pada tanahlah tergantung hidup mereka, Tuhan sendiri mengatur pembagian tanah lewat undi (Yos. 14:1-2; 18:1-10) yang luasnya untuk masing-masing keluarga tidak sama tergantung besar kecilnya keluarga (Bil. 26; 34; Yos. 13-19). Lewat para pemimpin umat pada waktu itu Tuhan telah membagi-bagi tanah keluarga dengan adil (Ul. 19:14; Ayb. 24:2; Ams. 23:10). Maka, batas-batas tanah keluarga sudah tetap dan tidak boleh di geser-geser. Dikarenakan itu semua telah di tetapkan oleh Allah maka tidak seorangpun dapat menggeser batas ataupun juga menjual tanah tersebut. Karena bangsa israel hanya pendatang di tanah Kanaan, yang memiliki tanah itu merupakan Allah.

Tetapi apabila kepepet, tanah warisan dapat dijual, namun tanah itu bisa ditebus lagi oleh yang bersangkutan atau oleh kerabatnya yang mampu, jikalau tidak maka tanah itu akan tetap dikembalikan pada tahun Yobel. ${ }^{17}$ Jadi, tanah bukan hanya persoalan kepemilikan, tetapi tanah itu juga menyangkut dengan hubungan mereka dengan Allah itu sendiri. Nyatalah bahwa tanah bagi bangsa israel adalah sesuatu yang sakral, dan bukan hanya persoalan ekonomi, haruslah dijaga dengan baik.

Berdasarkan penjelasan di atas, tak heran Nabot menolak memberikan tanahnya kepada Ahab, walapun posisi Ahab sebagai raja. Karena tanah menjadi suatu entitas kehidupan bangsa Israel sebagai umat Allah. Bahkan sebagai tanda perjanjian, yang mengingatkan sejarah penyertaan Allah, bagi perjalanan nenek moyang Nabot dari Babel ke tanah Kanaan.

\section{Kedudukan teks 1 Raja-raja 21:1-16 dalam keseluruhan kitab 1 Raja-raja.}

1 Raja-raja merupakan kitab yang di mana kelanjutan dari kitab Samuel, dan kitab Rajaraja ini termasuk dalam Deuteronomis, dan kitab Raja-raja merupakan penutup dari Deuteronomis. Kitab ini merupakan kisah pertentangan Ahab dengan Elia, di mana Elia yang mewakili orang Israel yang benar menentang tindakan-tindakan raja dan ratunya yang tidak sesuai dengan Hukum Tuhan. Israel pada saat itu bisa dikatakan berada pada simpangan jalan. ${ }^{18}$

Sumber utama dalam teks 1 Raja-raja 21 adalah Masoretik, Septuaginta, dan Naskah laut mati. Dalam teks ini, sebuah penghinaan yang dilakukan oleh Izabel kepada bangsa Israel, dengan menyita kebun anggur Nabot (1 Raj. 1-26), di mana sebagaimana yang telah diperintah Tuhan bahwa tanah itu tidak boleh dijual, tetapi haruslah diwariskan turun-temurun dalam kehidupan bangsa Israel. Karena itu Nabot terkejut dengan keinginan Ahab untuk membeli kebun anggurnya. Dan Nabot pun menolak, untuk tidak

\footnotetext{
16 Ibid

17Karman, Bunga Rampai Teologi Perjanjian Lama, 82.

18 W.S. Lassor, D.A. Hubbarad, F.W. Pengantar Perjanjian Lama I (Jakarta: BPK. Gunung Mulia, 2013),
} 372. 
menjualnya kepada Ahab, namun Ahab sungguh merasa tidak senang, sehingga Izebel istri Ahab menggunakan kekuasaan Nabot untuk mengambil tanah Nabot dan membunuh nabot dengan kesaksian palsu. Elia sangat marah melihat tidakan Izebel yang tidak berprikemanusian, dan menghadapkan Ahab di Yisrael dan mengumumkan hukuman Tuhan atasnya. ${ }^{19}$

\section{Analisis Kata}

Dalam analisis ini, penulis melihat dan menganalisis kata yang kurang jelas maknanya dalam perikop, agar memudahkan penulis untuk menganalisis kata yang maknanya kurang jelas, maka penulis menggunakan Software Bible Works ,Sabda, dan Kamus Ibrani. Dalam perikop ini ada beberapa kata yang memiliki makna kurang jelas, dan perlu dianalisis secara mendalam, untuk memudahkan penulis menafsirkan perikop. Beberapa kata di perikop ini yang menurut penulis perlu dikaji apa maksud dan makna yang terkandung dari kata tersebut.

Di dalam ayat 3 Jawab Nabot kepada Ahab: "Kiranya TUHAN menghindarkan aku dari pada memberikan milik pusaka nenek moyangku kepadamu!" Ayat itu memicu penulis untuk bertanya apakah yang dimaksudkan Nabot ungkapan milik pusaka, mengapa nabot menyebutkan milik pusaka dalam teks. אֶת (et-nakhala) terdiri

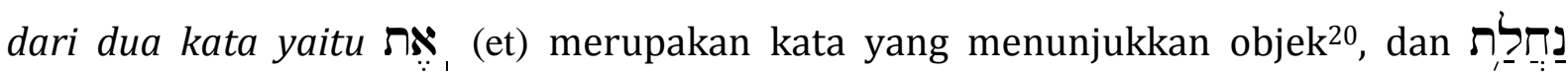
(nakhala) yang artinya adalah warisan, dalam NAS, NET, diterjemahkan "inheritance" yang juga artinya adalah warisan. Sedangkan TB, TL sendiri menerjemahkan sebagai "milik pusaka", yang menurut KBBI adalah peninggalan orang yang telah meninggal; warisan.

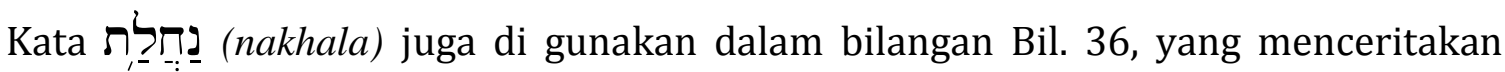
tentang hak waris kepada anak-anak perempuan, mereka berhak mendapatkan warisan dari ayahnya (Tanah), dan tidak boleh memperpindah tangan kepada suku lain, karena tanah atau warisan yang dimaksudkan adalah pemberian dari TUHAN sebagai milik pusaka yang sangat penting bagi bangsa Israel. Warisan yang dimaksud dalam 1 Rajaraja 21:3 merupakan milik pusaka yang berasal dari nenek moyang bangsa Israel, yang adalah tanah, dikarenakan tanah adalah pemberian Tuhan, dan merupakan suatu tanda suatu hubungan yang dekat dengan Tuhan.

Allah mengatakan kepada orang Israel bahwa mereka bukan pemilik sesungguhnya dari tanah, karena tanah itu adalah milik-Nya; mereka hanya merupakan pengurusnya saja, (Im 25:23-28) Maka menurut penulis dalam 1 Raja-raja 21:3 mengapa Nabot menolak menjual, atau menukarnya dengan tanah lain, karna persoalan pemahaman bahwa tanah adalah warisan atau identitas kedekatan Tuhan dengan mereka. Dengan demikian, alasan utama Nabot menolak atau menukarkan tanahnya dalam 1 Raja-raja

${ }^{19}$ W.S. Lassor, Hubbarad, F. W, Pengantar Perjanjian Lama I (Jakarta: BPK. Gunung Mulia, 2013), 376.

${ }^{20}$ D. L. Baker dan A. A. Sitompul, Kamus, “Warisan”, 14. 
21:3 terkait dengan pemahaman bahwa tanah adalah warisan atau identitas kedekatan Tuhan dengan umatNya.

Dalam teks 1 Raja-raja 21, selain masalah pusaka ada pula yang perlu di analisis yaitu dalam ayat 19 "Katakanlah kepadanya, demikian: Beginilah firman TUHAN: Engkau telah membunuh serta merampas juga! Katakan pula kepadanya: Beginilah firman TUHAN: Di tempat anjing telah menjilat darah Nabot, di situ jugalah anjing akan menjilat darahmu." Mengapa Tuhan menyampaikan pesannya lewat Nabia Elia dengan mengatakan bahwa anjing akan menjilat darah Ahab di tempat dimana darah Nabot di jilat anjing. Apa maksud dari kata itu, mengapa ada anjing yang menjilat darah Ahab.

Kata לר: לק: (laqaq) yang berati "lick up"21 atau menjilati digunakan dalam KJV, NIV, AST, dan merupakan terjemahan yang sma digunnakan dalam Alkitab Terjemahan Baru

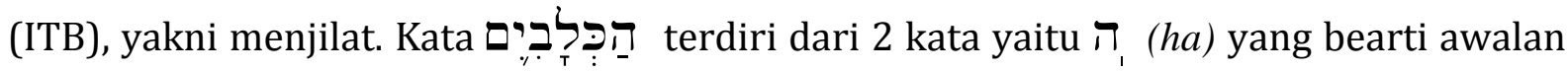

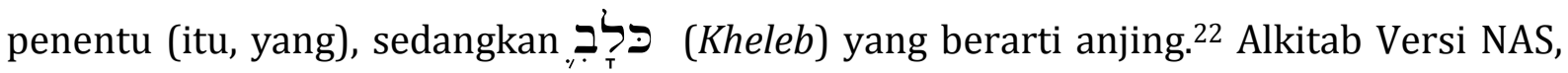
NET menerjemahkannya sebagai "dogs" dengan penekanan pada bentuk jamak, sementara ITB menekankan bentuk tunggal. Penulis lebih sepakat dengan teks asli, dan

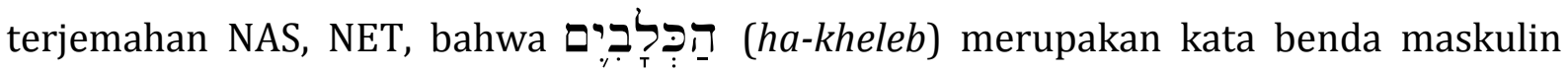
jamak, diterjemahkan sebagai anjing-anjing.

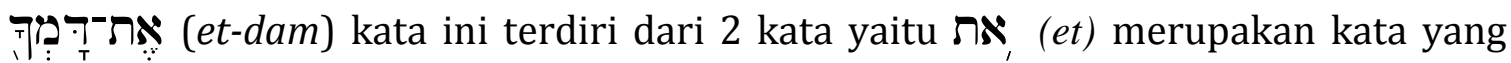
menunjukkan objek ${ }^{23}$ dan ${ }_{T}^{\top}$ (dam) merupakan kata yang berarti darah. ${ }^{24}$ Beberapa terjemahan seperti, NAS, NET juga merujuk kepada darah (blood). Usulan terjemahan dari penulis adalah, "anjing-anjing akan menjilati darahmu." Lady paula R. Mandalika mengatakan, ketika dalam bagian ini Nabi Elia hanya menyampaikan kritik atas ketidakadilan yang diperbuat oleh Ahab. Melalui Elia, Tuhan menegur Ahab dan istrinya yang membunuh Nabot. ${ }^{25}$ Menurut Haag anjing sudah dikenal sejak kuno sebagai binatang berburu dan binatang piaraan di rumah. Anjing yang tidak bertuan, yang berkeliaran dan makan bangkai busuk (Mzm. 68:24) dipandang najis (Kel. 22:30) membahayakan (Ams. 26:17; Kel. 11:7). ${ }^{26}$ Dan anjing juga merupakan istilah cemoohan, bahkan di dalam Mazmur 15:26 sebagai seseorang yang menghianati Allah.

Ensiklopedia Masa Kini menjelaskan tentang anjing pada masa itu

Umumnya di daerah Timur Tengah, anjing pada dasarnya adalah binatang pemakan bangkai; dan kendati anjing sangat berguna untuk menghabiskan hidangan yang terbuang, pada kodratnya memang anjing adalah kotor dan merupakan pembawa

${ }^{21}$ Bible Works, V.7.

${ }^{22}$ D. L. Baker dan A. A. Sitompul, Kamus "anjing", 19.

23Ibid 14.

24Ibid

${ }^{25}$ Lady Paula R. Mandalika, Teologi Tanah: Prespektif Kristen terhadap Ketidakadilan Sosio-ekologis di Indonesia (Makassar;Oase Intim, 2015), 246.

26Sabda Elektronik, V.4. 
penyakit, justru tak dapat dijamah tanpa yang menjamahnya menjadi najis. Ibrani kelev tanpa diragukan ialah anjing setengah liar, yang berkeliaran di luar rumahrumah menantikan bangkai atau sisa makanan yang akan dibuang. ${ }^{27}$

Menurut penulis, mengapa dalam ayat 19 dikatakan Anjing akan menjilat darah Ahab, bukan hanya persoalan krtitik dan penghukuman tetapi memilki makna yang terkandung di dalamnya. Pada saat itu konteks bangsa Israel, anjing adalah hewan yang kotor dan najis, bahkan melambangkan seorang penganiaya umat Allah. Anjing merupakan sebuah penyataan bahwa Ahab adalah penganiaya umat Allah yang najis, yang merebut kebun anggur dan membunuh pemiliknya, sesuatu perbuatan yang keji menurut Allah.

\section{Pembahasan}

\section{Tafsiran 1 Raja-raja 21 dan Konflik Agraria di Indonesia}

Dalam perikop 1 Raja-raja 21 ini, menceritakan tentang seorang raja yang berkuasa pada saat itu, yakni Ahab, mengalam konflik dengan rakyat biasa yang bernama Nabot, di mana Elia hadir menjadi perantara untuk menyampaikan pesan dan hukuman Allah kepada Ahab. Melihat peristiwa ini, kita melihat konflik antara Penguasa dan orang kecil (petani) Nabot, mengapa terjadi perebutan lahan, bahkan Ahab sampai membunuh Nabot. Yang pertama ternyata kebun anggur Nabot sangatlah dekat dengan Istana Ahab (ay.1), ada transaksi yang di tawarkan oleh raja Ahab, bahwa dia akan menukarkan dengan kebun anggur yang baik, bahkan raja Ahab menawarkan untuk ditukarkan dengan uang pada saat itu. Ahab adalah Putra dan pengganti Omri, pendiri satu dinasti, yg memerintah sebagai Raja ke-7 Israel selama 22 tahun, karna pada tahun 874-852 sM (1Raj 16:28). Ia menikah dengan Izebel, putri Etbaal, raja orang Sidon dan imam orang Astarte yang memiliki kekuasaan kolonial yang dominan di bidang ekonomi dan perdagangan (kapitalis).

Ahab memperkuat kota-kota Israel (1 Raj. 16:34; 22:39) dan melakukan pekerjaan besar di ibu kotanya sendiri, yaitu Samaria. Seperti terlihat dalam penggalian yang diadakan (1 Raj. 16:32). Istananya dihiasi dengan gading (1 Raj. 21:1; 22:39; band: Am 3:15). Selama kurun pemerintahannya sering terjadi perang dengan Siria (band: 1 Raj 22:1), khususnya melawan Ben-Hadad yang - bersama sekutunya - mengepung Samaria tapi dipukul mundur (1 Raj. 20:21). Kemudian, dalam pertempuran dekat Afek, Ahab dengan gemilang mengalahkan Ben-Hadad, tapi membiarkannya hidup (1Raj 20:26-30), mungkin guna memulihkan konsesi dagang di Damsyik, seperti izin yg diberikan kepada pedagang-pedagang Siria di Samaria. Kegiatan perekonomian berlangsung dengan baik, dan berkembang, sehingga membuat segala sesuatu dinilai secara ekonomis, jadi tidaklah heran bahwa Ahab ingin menukarkannya dengan uang kebun anggur yang dimiliki oleh Nabot. ${ }^{28}$

27Ibid.

28Ibid. 
Namun yang terjadi pada saat itu, dengan tegas Nabot menolak memberikan kebunnya (ay.3), dan respon dari Ahab merasa kesal, itu ditunjukan ketika ia kembali ke Istana dan tidak mau makan. Mengapa pada saat itu Raja Ahab tidak langsung menggunakan kekuasaannya untuk mengambil kebun anggur, tampaknya dia mengerti bahwa tanah milik pusaka bangsa Israel tidaklah boleh berpindah tangan, dikarenakan dia sendiri adalah orang Israel yang tentunya tahu bahwa nakhala merupakan warisan turun temurun bangsa Israel dan itu adalah suatu bentuk identitas kedekatan dengan Tuhan.

Tetapi jikalau dilihat dalam pembacaan, sangat jelas bahwa, perampasan dan pembunuhan terjadi atas ide dan perencanaan Izebel dengan menggunakan nama Raja Ahab untuk merebut kebun anggur Nabot. Di sini penulis melihat bahwa Raja Ahab gampang dipengaruhi oleh istrinya yang sangat keji dan kejam. Izebel merupakan Putri dari Etbaal, raja imam Tirus dan Sidon. Dia kawin dengan Ahab, guna menguatkan persekutuan Tirus dengan Israel. Dengan persekutuan ini Omri, ayah dari Ahab, berusaha meredakan permusuhan Damsyik dengan Israel (880 sM). Di Samaria, tempat tinggal Izebel yang baru, disediakan sarana yg perlu baginya untuk melanjutkan ibadah kepada dewanya, yaitu dewa Baal (1 Raj. 16:31-33). ${ }^{29}$ Wataknya keras dan bersifat menguasai, menuruti kehendak sendiri dan bersifat memaksa. Dia penyembah fanatik dewa Melkart, yaitu Baal orang Tirus. Nabi dewa ini pada zaman pemerintahan Ahab berjumlah 450 orang, ditambah lagi dengan 400 nabi dewi Asyera (1Raj 18:19). Jadi tidaklah heran jikalau Izebel mempunyai ide yang kejam dan keji kepada Nabot untuk merebut kebun anggurnya. ${ }^{30}$

Dalam kematiannya Nabot difitnah dengan memakai saksi dusta bahwa ia telah menghujat raja dan Allah di depan orang banyak. Dengan fitnahaan itu, maka Izebel berhasil memprovokasi rakyat, dengan menggunakan nama raja, dan menggunakan dua orang dursila yang merupakan saksi palsu untuk mengatakan bahwa Nabot telah menghujat Allah dan Raja, dan tentunya bagi orang Israel ketika itu di lakukan, maka akan di hukum dengan rajam batu sampai mati. Di sini dapat dilihat, bahwa kekejian yang dilakukan Izebel dan Ahab yang tidak berperi kemanusiaan, dengan menggunakan kekuasaan untuk merebut kebun anggur Nabot, dan jikalau dilihat bahwa kebun tersebut tidaklah menjadi sesuatu hal yang sangat penting bagi Raja Ahab, tetapi semua itu di tukarkan dengan kematian dari Nabot.

Menurut Ira D Mangalilo dalam tulisannya bahwa ketika memahami dan merekonstruksi yang lain sebagai hal yang negatif. Hal ini kemudian menjustifikasi tindakan kekerasan terhadap Sang lain. ${ }^{31}$ Itu terlihat dalam peristiwa Ahab dan Nabot, menganggap bahwa Raja Ahab adalah yang memiliki kuasa dan menganggap Nabot

\footnotetext{
${ }^{29}$ Ibid.

30Ibid.

31Ira D. Mangililo, Hermenetika Postkolonial (Toraja: ISBI, 2016), 24.
} 
(Sang lain) yang hanya rakyat kecil (petani), sehingga Ahab menggunakan dominasi kekuasaannya itu untuk mengambil kebun Nabot dan membunuh Nabot dengan keji.

Setelah Nabot mati, Ahab mengambil kebun anggurnya, Tuhan yang mahaadil melihat ketidakadilan yang terjadi, sehingga Ia mengutus Nabi Elia untuk menyatakan penghukuman kepada Ahab yang ternyata sudah terlalu banyak melakukan sebuah kesalahan (ay.17-18). Ketika Nabi Elia pada saat bertemu dengan raja Ahab, maka Ahab menganggap bahwa Nabi Elia merupakan Musuhnya (ay.20), mengapa demikian. Itu di karenakan beberapa hal, Ahab bersama istrinya telah menyetujui penyembahan Baal (1Raj 16:32-33), membunuh nabi-nabi Tuhan (1 Raj. 18:4, 13), melawan Elia (1 Raj. 19:1, 2). ${ }^{32}$ Dalam cerita ini sangat jelas bahwa Elia merupakan musuhnya, karena Elia memberitakan apa yang menjadi kehendak Tuhan, dan bahkan memberitakan apa yang menjadi hukuman Tuhan atas diri Ahab.

Malapetaka yang Tuhan nyatakan kepada Ahab, bahwa di tempat Nabot di bunuh maka di situ jugalah anjing akan menjilat darah Nabot. Bagi orang Israel anjing merupakan hal yang najis, dan merupakan simbol penganiaya Tuhan. Anjing menjilat darah Ahab sebagai tanda bahwa, ia adalah sesorang penganiaya umat Allah (Nabot), dan akan membunuh setiap generasi dari Ahab seperti hukuman yang sama seperti keluarga Yerobeam dan keluarga Baesa. Walaupun Ahab sudah melakukan apa yang keji di mata Tuhan, tetapi dia mengaku atas dosa-dosanya, dan Tuhan memberikan pengampunan terhadapnya, bahwa Tuhan tidak akan memberlakukan hukuman itu di zamannya, barulah di berlakukan ketika zaman anaknya.

Bukan hanya Ahab yang mendapatkan hukuman, tetapi juga Izebel yang sungguh kejam merencanakan pembunuhan ini. Izebel mendapat hukuman bahwa ia akan dimakan anjing di luar tembok, sungguh suatu kematian yang menjijikan dikarenakan anjing di luar tembok merupakan anjing liar, yang sungguh melambangkan sebuah kenajisan yang sangat miris atas apa yang telah dia lakukan (ay. 23). Nubuat Nabi Elia itu di genapi dalam (2 Raj. 9) seperti apa yang telah di nubuatkan oleh Nabi Elia. Penulis melihat bahwa dalam 1 Raja-raja 21 adalah suatu peristiwa ketidakadilan yang di lakukan Raja Ahab, dan juga sekaligus Allah menyatakan keadilan ditengah-tengah ketidakadilan yang dilakukan oleh raja Ahab. Itu terlihat dari penghukuman yang ada, bahkan hukuman yang Allah nyatakan kepada Ahab, merupakan sebuah simbol kenajisan dan penganiaya umat Allah.

Tanah bukanlah hal yang hanya dapat dilihat dari segi ekonomis saja, tetapi juga tanah perlu di pahami sebagai sebuah tanda, identitas kedekatan Tuhan dan umatNya, makanya dalam 1 Raja-raja 21:3 Nabot memiliki alasan yang jelas untuk menolak pertukaran dan pembelian tanah tersebut. Kematian nabot sangatlah tidak wajar dan Tuhan tidak tinggal diam melihat itu, seorang Nabi yang bernama Elia dengan berani menghadap raja Ahab dan menyatakan penghukuman Allah terhadapnya dan keturu-

${ }^{32}$ Sabda Elektronik, V.4. 
nannya, dan ternyata Ahab bersama istrinya Izebel telah melakukan banyak kesalahan yang mendukakan hati Allah, Ahab melakukan penyembahan berhala kepada dewa Baal, melawan dan bahkan membunuh para Nabi.

Walaupun Ahab telah melakukan dosa dan mendukakan hati Allah, keadilan dan kasih Allah tetap dinyatakan kepada Ahab, penulis melihat kasih Allah atas Ahab bahwa penghukumannya itu tidak akan terjadi di zamannya tetapi akan terjadi kepada keturunannya kelak. Itu terjadi karena Ahab mengakui setiap perbuatan dosanya kepada Tuhan, walaupun ada pengampunan dari Tuhan Ia tetap adil karena akan menyatakan penghukuman itu kepada keturunannya. Akhirnya penulis menyimpulkan bahwa, setiap ketidaktaatan menimbulkan dosa yang tidak saja berdampak pada diri sendiri, tetapi juga orang lain. Peristiwa Raja Ahab dan Nabot ini telah mengambarkan bahwa Allah akan tetap bersama umatNya yang tertindas dan bahkan membela mereka yang kecil.

Setelah penulis menemukan keadilan Tuhan dalam kisah 1 Raja-raja 21, dalam hal perebutan tanah, penulis tidak puas hanya sampai disitu saja. Tetapi dengam ini dapat memberi implikasi dengan persoalan tanah yang sangat krusial di Indonesia, dan menampakan banyak ketidakadilan. Persoalan agraria khususnya di Indonesia sungguh miris, dikarenakan persoalan ini berdampak pada persoalan kemanusiaan, dan bahkan sampai kepada kerusakan lingkungan yang membuat keseimbangan ciptaan menjadi rusak, hanya karena persoalan kapital, semuanya di nilai secara ekonomis. Perusahaan dan pemerintah bahkan saat ini bekerja sama, untuk mengeksploitasi tanah dan bahkan melakukan diskriminasi terhadap rakyat kecil, sehingga terjadi sebuah ketidak seimbangan dalam kehidupan manusia dengan alam dan mendatangkan bencana bagi manusia, bukan hanya bencana alam, tetapi juga sosial.

Konflik yang terjadi, melibatkan penguasa dan orang kecil, tentu jikalau ini terjadi maka orang-orang kecil akan kalah, dikarenakan orang kecil tidaklah berpendidikan dan miskin, sedangkan orang yang punya kuasa tentunya memiliki pendidikan yang tinggi dan ekonomi yang mapan. Sangatlah miris ketika melihat keadaan orang-orang kecil ditindas oleh para penguasa, hukum bisa saja dipakai oleh mereka yang mempuyai kuasa untuk membenarkan tindakan mereka, walaupun itu terlihat tidak adil. Jikalau melihat peristiwa konflik agraria, apa bedanya para pemilik perusahaan dan penjajah dahulu yang mengambil tanah milik masyarakat, dan kekayaan tanah itu dinikmati oleh orang tertentu, sedangkan masyarakat setempat tidak mendapatkan apa-apa, melainkan mengemis di tanah sendiri.

Seperti yang terjadi dalam peritiwa 1 Raja-raja 21, penulis melihat bahwa ada ketidakadilan dalam perampasan tanah Nabot. Nabot di hukum dan mati dalam ketidakadilan. Peristiwa tersebut juga terjadi dalam kehidupan sekarang, kebanyakan penguasa saat ini dikaburkan pemahamannya, hanya menganggap bahwa tanah itu dapat di nilai secara ekonomis. Mengeruk keuntungan yang banyak dari tanah tersebut, tidak 
memikirkan soal bagaimana kehidupan masyarakat jikalau terus di eksploitasi dan berujung pada kerusakan lingkungan, bahkan terjadi diskriminasi terhadap orang-orang marginal (petani). Proses penaklukan masyarakat atau perampasan tanah, di abad ini semakin masif dengan jargon pembangunan dan modernisasi di berbagai wilayah di Indonesia. Orang kampung adalah orang-orang yang di anggap kalah. Pengetahuan mereka dianggap remeh dan keberadaan mereka dianggap tiada dan tanah mereka diambil. ${ }^{33}$

Melihat sosok nabi Elia, yang mengadvokasi orang kecil, dan raja Ahab menyadari kesalahannya membunuh dan bahkan memfitnah Nabot. Sangat menarik bahwa nabi Elia merupakan sosok yang betul berani untuk menyatakan kebenaraan. Sosok nabi Elia, harusnya diperankan oleh gereja pada saat ini, tetapi nyatanya melihat konflik agraria gereja tinggal melihat persoalan ini.

Saat ini, suara yang lantang untuk melawan ketidakadilan sangatlah jarang di temui, khususnya gereja, yang harusnya menjadi tokoh untuk menyatakan suara kenabian di atas ketidakadilan yang terjadi di tengah-tengah kehidupan orang kecil yang di rampas haknya. Gereja tidak boleh tinggal diam melihat persoalan ini, tidak hanya mendoakannya tetapi juga ikut bersama-sama dengan orang yang ditindas dan diambil haknya. Dimana gereja yang selalu membicarakan soal keadilan, dimana gereja yang selalu membicarakan tentang kasih dan keselamatan, dan bahkan gereja saat ini seolah-olah tidak peduli akan persoalan ini. Dalam 1 Raja-raja 21, Allah sendiri tidak tinggal diam melihat persoalan ketidakadilan. Dia mengutus nabi Elia untuk menyampaikan pesan penghukuman atas ketidakadilan yang dilakukan raja Ahab, sehingga orang-orang kristen harusnya peka terhadap persoalan ketidakadilan, karena Allah sendiri tidak menghendaki ketidakadilan dalam kehidupan umatNya.

Pemerintah sendiri, lebih banyak pro kepada perusahaan daripada masyarakat kecil, pemerintah memberikan tanah yang luas kepada perusahaan sedangkan masyarakat sendiri tidaklah di perhatikan haknya. Perusahaan hanya mencari keuntungan, dan bahkan mirisnya bahwa keuntungan itu hanya dirasakan oleh pemodal, tidak sedikitpun menguntungkan masyarakat. Dan itu adalah akar dari konflik agraria, berdampak bukan hanya persoalan sosial, tetapi juga kepada persoalan ekonomi.

Peraturan yang ada saat ini yang tumpul keatas dan tajam kebawah, dipakai oleh para penguasa untuk melegitimiasi ekspansi perluasaan tanah mereka, dan mengusur kampung masyarakat dan hutan masyarakat adat. Dan masyarakat tergusur di atas tanahnya sendiri. Konflik agraria akan terus berlanjut, dan akan terus ada jikalau tanah di eksploitasi yang hanya akan menguntungkan pihak tertentu, ada sebuah ketidakadilan di dalamnya, tentu orang miskin dan kecillah yang terkena dampaknya.

${ }^{33}$ Dominggus Elcid Li, Teologi Tanah; Perspektif Kristen terhadap Ketidakadilan Sosio-Ekologis di Indonesia, 227. 
Peran Nabot dalam teks ini, perlu untuk menjadi point penting, untuk impikasinya bagi masyarakat kecil saat ini. Ia menjadi seorang yang berani untuk mempertahankan haknya, dan tidak memberikan saja tanahnya kepada raja Ahab. Mengapa sedemikian berani menolak keinginan raja Ahab untuk menukarkan tanahnya? Karena ia yakin, bahwa tanah tersebut adalah sebuah pemberian dari Tuhan, dan tidak boleh sewenangwenangnya saja digunakan. Pertama, dalam masyarakat saat ini, tentu banyak yang sewenang-wenang mempergunakan haknya, dan tidak bertanggung jawab, kecuali hanya memikirkan keuntungan. Belajar dari Ahab, ia bahkan mempertahankan haknya dan mengorbankan nyawanya. Kedua, keberanian Nabot. Masyarakat kecil saat ini, harus berani melawan kesewenang-wenangan para pemilik modal dan pemerintah, yang merebut hak mereka.

Di sinilah peran gereja untuk menyorakkan suara kenabiaannya kepada pemerintah, di atas ketimpangan hukum yang tidak pro kepada masyarakat kecil. Gereja tidaklah boleh tinggal diam akan persoalan ini, karena persoalan ketidakadilan tidaklah dikehendaki oleh Allah, diam bukanlah solusi yang baik, tetapi diam akan membuat penindasan bertambah. Gereja harus memenuhi panggilannya di dunia, di tengahtengah ketimpangan sosial, hukum, ekonomi, dan politik. Ia harus membela bagi mereka miskin dan melawan mereka yang penuh dengan keserakahan untuk mengeksploitasi milik orang miskin dan kecil.

\section{Kesimpulan}

Tanah tidak boleh dipahami secara ekonomis saja, tetapi juga dipahami sebagai pemberian dari Tuhan yang harus dijaga dan dirawat dengan baik; dengan demikian konflik agrarian, bahkan pengekspolitasian tanah tidak akan terjadi lagi. Tanah harus dipahami secara sakral, karena tanah merupakan suatu indentitas hubungan yang dekat antara manusia dengan Tuhan. Gereja seharusnya menjadi seperti nabi Elia, yang merupakan utusan Tuhan untuk menyatakan keadilan. Karena saat ini, banyak konflik agraria yang melibatkan para penguasa yang dengan sewenang-wenang mengunakan kuasanya untuk merampas tanah-tanah milik orang marginal, untuk kepentingan ekonomi. Sudah seharusnya tanah itu dipahami sebagai anugerah dari sang kuasa, untuk kepentingan bersama, bukan hanya kepentingan sekelompok orang. Di sinilah tugas gereja, menjadi utusan Tuhan untuk menyampaikan keadilan di antara umat Allah, atas ketimpanganketimpangan sosial.

\section{Referensi}

Alkitab Perjanjian Lama dan Perjanjian Baru, Jakarta: Lembaga Alkitab Indonesia (LAI), 2005

Alkitab Penuntun Hidup Berkelimpahan, Jakarta: Lembaga Alkitab Indonesia (LAI), 2007 Sabda Elektronik, V.4

Araf, Al dan Puryadi, Awan. Perebutan Tanah . Yogyakarta: Lappera, 2002. 
Blommendal, J. Pengantar kepada Perjanjian Lama, diterjemahkan P. S Naipospos Jakarta:BPK Gunung Mulia, 2008.

Hayes, John H. Holladay, Carl R. Pedoman Penafsiran Alkitab, terjemahan Ioanes Rakhmat Jakarta: BPK. Gunung Mulia, 2013.

Henslin, James M. Sosiologi, dengan Pendekatan Membumi. Jakarta: Erlangga, 2006.

Karman, Yonky. Bunga Rampai Teologi Perjanjian Lama. Jakarta: BPK. Gunung Mulia, 2013.

Keoswahyuno, Imam. Sosiologi hukum dan perubahan. Jakarta:Yayasan Pustaka Obor Indonesia, 2009.

Komisi Kitab Suci Kepausan, Penafsiran Alkitab dalam Gereja, ter. Indra Sanjaya. Yogyakarta: Kansinus, 2007.

Lasor, W.S. Hubbarad, D.A. Bush, F.W. Pengantar Perjanjian Lama 1, terjemahan Werner Tan dkk Jakarta: BPK. Gunung Mulia, 2013.

Laffey, Alice L. "Tafsir I-II Raja-raja”. Dalam Tafsiran Alkitab Perjanjian Lama terjemahan A.S Hadiwiyata. Yogyakarta: Kanisius, 2002.

Muryanti, Damar D. Nugroho, Rokhiman. Teori Konflik \& Konflik Agraria di Pedesaan, Bantul: Kreasi Wacana, 2013.

Puspito, Hendri. Sosiologi Agama. Yogyakarta: Kanisius, 1983.

Ramadhiani, Arimbi. 2017 “Konflik Agraria Dipicu Ekspansi Perkebunan, Properti, dan Infrastruktur"http://properti.kompas.com/read/2016/01/06/100000821/Sejak.200 4.Konflik.Agraria.Mencapai.1.772.Kasus. (Di akses pada 13 Mei 2016).

Singgih, Emmanuel Gerrit. Dua Konteks. Jakarta: BPK Gunung Mulia, 2009. . Mengantisipasi Masa Depan. Jakarta: BPK Gunung Mulia, 2005.

Sumaryono, E. Hermeneutika Sebuah Metode Fisafat Yoyakarta: Kanisius, 1999.

Susanta, Yohanes Krismantyo. "Anak Manusia: Suatu Reinterpretasi terhadap Konsep Mesianis Yahudi." (2014). http://repository.seabs.ac.id/handle/123456789/304 (diakses 25 Mei 2019).

Syahrizal, Darda. Kasus-kasus Hukum Perdata Indonesia. Yogyakarta:Pustaka Grhatama, 2011.

Upe, Ambo. Tradisi Aliran dalam Sosiologi. Jakarta: Rajawali pers, 2013.

Waluya, Bagja. Sosiologi Menyelami Fenomena Sosial di Masyarakat. Bandung: Setia Purna Inves, 2007. 